\title{
Selections from the history of environmental pollution, with special attention to air pollution. Part 1
}

\author{
L. Makra* \\ University of Szeged, Department of Climatology and Landscape \\ Ecology, H-6701 Szeged, PF. 653, Hungary \\ (e-mail: makra@geo.u-szeged.hu)

\section{P. Brimblecombe}

School of Environmental Sciences, University of East Anglia, Norwich

NR4 7TJ, UK

(e-mail: p.brimblecombe@uea.ac.uk)

\begin{abstract}
Several comprehensive publications have been issued recently on the environmental pollution of past times (e.g. Tylecote, 1976; Nriagu, 1983a; Brimblecombe, 1987a; Goldstein, 1988; Healy, 1988; Brimblecombe and Pfister, 1990; Hughes, 1993; Markham, 1994; Brimblecombe, 1995; Karatzas, 2000, 2001; McNeill, 2001; Mészáros, 2001). The aim of this study is to give an overview of information on the subject - mainly related to ancient times.
\end{abstract}

Keywords: copper mining, copper pollution of the atmosphere, lead mining, lead pollution of teeth, lead pollution of the atmosphere.

Reference to this paper should be made as follows: Makra, L. and Brimblecombe, P. (2004) 'Selections from the history of environmental pollution, with special attention to air pollution', Int. J. Environment and Pollution, Vol. 22, No. 6, pp. 641-656.

\section{Biographical notes}

László Makra is an associate professor at the Department of Climatology and Landscape Ecology, University of Szeged, Hungary. He holds a PhD in meteorology, and teaches courses in general meteorology, physical and regional climatology, air pollution, and air quality. His research fields were previously analysis of large-scale weather situations over the Carpathian Basin and spatial and temporal teleconnections of the global sea-level pressure field. Recent research interests are local and mesoscale air pollution (urban air pollution, background aerosols) and statistical climatology. He takes part in international research projects: the elemental composition of atmospheric aerosol (Northwestern China, Indonesia, Brazil) and urban air pollution (Germany).

Peter Brimblecombe is Professor in Atmospheric Chemistry at the School of Environmental Sciences, University of East Anglia. He did a PhD on the aqueous chemistry of sulfur dioxide in the atmosphere at the university in Auckland, New Zealand. He maintains an interest in atmospheric sulfur

\footnotetext{
* Author for correspondence.
} 
chemistry, and currently is chiefly concerned with the thermodynamics of the concentrated aqueous aerosol and its effects in the chemistry of polar stratospheric cloud droplets that play a role in ozone depletion. He continues to be interested in long-term changes in urban air pollution and its effects on health and buildings. The historical aspects of this work formed the subject of a book, The Big Smoke. His interest in material damage by air pollutants has not been restricted to outdoor environments: he has done some work on the museum atmosphere and has a continuing interest in the process of damage to cultural materials by air pollutants. He has written on the history of acid rain, early air pollution in Manchester, and the influence that urban air pollution had on architecture in late Victorian England. He was appointed senior editor of Atmospheric Environment in 1990.

\section{Pollution of the environment in ancient times}

Environmental pollution is coeval with the appearance of humans. When Homo sapiens first lighted fire, its smoke provided the first medium of environmental pollution. The burning of fuels for heating and cooking has contributed to the air pollution of inner spaces. The walls of caves, inhabited several thousands of years ago, are covered with thick layers of soot. The presence of smoke must have made breathing difficult and must have irritated the eyes in the confined space as well. Most of the lungs of mummified bodies from the Palaeolithic (however, there are few of them) have a black tone. In the first inhabited areas smoke was not driven away (one of the practical reasons might have been protection against mosquitoes) and the people dwelling in these inner areas found shelter in the smoke (McNeill, 2001). [Millions of people live this way today. In 1993, when we were in Nepal trekking in the Langtang National Park, we visited many small villages and found accommodation at local houses on the southern slopes towards the High Himalayas. The smoke of fire is not driven away from the buildings here, even today. The walls of the houses are built of metamorphic slates with no bonding, carrying roofs covered with rush matting. When there is fire, it produces a thick smoke inside the house, irritating the eyes and making breathing difficult. It is impossible to sleep; one can stay there for only a short time. And from the outside, the house looks as if it is on fire, smoke is streaming out through the slits and gaps of the walls.] Humans seem to have been living together with this unhealthy form of air pollution for many thousands of years.

Environmental pollution was responsible for several kinds of illness in early times. The very first polluting material might have been the human faeces. Bowel bacteria living in the human body, such as Escherichia coli, might have easily got into drinking water, infecting the early humans. This type of 'environmental pollution' causes illnesses affecting several millions of people even today. In China, where a comprehensive system was developed for waste disposal even in ancient times, the use of human faeces as a fertilizer was an important element of agriculture even many thousands of years ago. The high productivity of the alluvial plain in the eastern part of the country has been maintained this way for over 4000 years. This tradition is being followed even today in several regions of China. As Han Suyin says, 'In Chengtu (the capital of Sechuan Province) those families, who owned the city sewers and this way could sell the accumulated faeces in the countryside, belonged to the richest ones even in the 20th century (till 1949)' (Markham, 1994). The fertilization of rice-paddies with faeces 
contributed largely to the pollution of groundwater, which is thus rendered unsuitable for drinking in the whole of tropical Asia. However, if water is boiled, resulting in the precipitation of salts, it becomes totally tasteless. The tradition of flavouring boiled water with tea leaf comes from China and it started spreading in the empire about $2000 \mathrm{BC}$ and then all over Asia (Makra, 2000).

Dust pollution also appeared in early times. Some of this was of natural origin, and Chinese and Korean writers have noted the easterly transfer of yellow Loess (sometimes called Kosa dust) for thousands of kilometres (e.g. Chun, 2000). According to Janssens, in the New Stone Age people mining flint from the embedding limestone in the stone mines day by day might have suffered from silicosis, for example in Obourg (Markham, 1994). The day-long inhalation of dust must have been the underlying factor. Sometimes the geographical location of an area was responsible for the outbreak of certain diseases. Investigations revealed that near Broken, in the territory of recent Zambia, Hominides who lived about 200000 years ago suffered from lead poisoning. The reason for this illness was the transport of lead into the spring located next to the cave from a neighbouring streak of ore (Markham, 1994).

The harmful activities of ancient civilizations caused long-lasting changes in the environment, the effects of which can be experienced even today. However, these effects appeared only at a regional scale without causing any global changes. Increasing soil alkalinity on the floodplains of the Tigris and Euphrates rivers between $3500 \mathrm{BC}$ and $1800 \mathrm{BC}$ resulted in a gradual decrease of the productivity of Sumerian agriculture. Water used for irrigation raises the groundwater table, and if the redundant water is not channelled away, then soils become saturated with water, resulting in the dissolution of salts and their precipitation on the surface in the form of an impermeable layer. Sumerian people noted this process as the following: 'the soil surface turned white'. Water used for irrigation gradually makes the region more and more unsuitable for agricultural production via leaching of the soils. This phenomenon largely contributed to the decline of Sumerian culture (Markham, 1994; Mészáros, 2002).

Babylonian and Assyrian law included clauses that affected neighbours' property. Although the earliest laws, those of Hammurabi (23rd century BC) relate mostly to water (Driver and Miles, 1952), smoke was typically treated in the same way in ancient law (Brimblecombe, 1987b). Around 200 AD the Hebrew Mishnah and its interpretation through the Jerusalem and Babylonian Talmud detail pollution issues (Mamane, 1987).

In ancient times air pollution had substantial consequences only in the cities. The air of these early towns, as in some recent settlements as well, was filled with the penetrating smell of decaying organic domestic waste, rotting meat as well as human faeces. During a siege, when there was no chance to remove these waste materials emitting aggressive smells, unbearable conditions prevailed in these settlements. According to Egyptian historical records, when Nubian troops enclaved the city of Hermopolis, which is situated on the left bank of the Nile half-way between Theba and Memphis, the inhabitants rather surrendered pleading for mercy, than to further bear the smell of their own town air (Brimblecombe, 1995). In the ancient cities, pollution deriving from unpleasant odours was generally important. Aristotle (384-322 BC) set a rule in his work Athenaion Politeia, according to which manure should be placed outside the town, at least $2 \mathrm{~km}$ away from the town walls (Mészáros, 2001). Smoke-stained marble in antique towns giving them a greyish tone. This annoyed several classical poets as well [e.g. Horace (65 $\mathrm{BC}$ to $8 \mathrm{AD})$ ] and persuaded ancient Jews, among others, to introduce a list of laws 
(Mamane, 1987). In ancient times smoke and soot represented the two major media of air pollution.

There are several examples of environmental pollution in China, too. Before the Tang era (618-907), the firs on the mountains of Shantung were logged and burned, then in the Tang era the slopes of the Taihang mountains, located along the border of the Shansi and Hopei provinces, became barren (Schäfer, 1962). Similarly, during the Tang dynasty forests were cut around Loyang, the capital, in a circle with a radius of 200 miles. The trunks of the trees were mostly used as firewood and partly burned in order to get ink for the governmental offices (Epstein, 1992).

Urban air pollution depends on the dimension of the given settlement, on the extent of the built-up territory, as well as on the nature of the industrial activity, especially on the use of traditional fuels. As urbanization progressed in China, in the Mediterranean Basin and in North-western Africa, from about 1000 AD, more and more people lived in smoky and sooty surroundings. Maimonides, the philosopher and physicist (1135-1204), who had comprehensive experience of the towns of that era, from Cordoba to Cairo, found that urban air is 'stuffy, smoky, polluted, obscure and foggy'. Furthermore, he thought that this condition is produced by 'dullness preventing understanding, lack of intelligence and amnesia' of the inhabitants (Turco, 1997).

On the other hand, traffic and transportation difficulties restricted the rate of air pollution within the cities. Industrial activities consuming the most energy (e.g. the production of tiles, glass, pottery, bricks and iron casting) were located near the forests, because the transportation of fuels in large amounts to the cities would have been too expensive. This way, though air pollutants of industrial origin made the air smelly, only a few people inhaled it. Port cities were partially exceptions, as ships could transport wood and charcoal more economically. Hence, Venice could maintain its glass industry, ensuring its energy supply by the transportation of wood from distant places. However, the majority of urban air pollution was derived from household fuels, such as manure or wood, but sometimes smokeless charcoal as well (McNeill, 2001). The air of the Chinese cities might have been extremely polluted, too, because the developed water transport system (Big Channel) enabled the use of large amounts of fuel, at least in the Sung capital, Kaifeng. This city, $500 \mathrm{~km}$ south of Beijing, was probably the first one in the world to convert its energy supply from wood to coal. The transition occurred at the end of the 11 th century, when the city had about one million inhabitants. However, the coal-heating period was short, because Mongolian troops destroyed Kaifeng in 1126 and those who remained in the city died from plague in the early 13th century (Hartwell, 1967).

Intensive environmental pollution appeared simultaneously with the development of societies. Extensive environmental losses occurred even in the earliest societies. Air and water were polluted, soils were destroyed and many animal and plant species were exterminated. However, environmental changes caused by the earliest societies were generally minor ones, and the original conditions were rapidly restored. Thanks to this, many people are not aware of the environmental losses triggered by the activities of early societies. Consequently, they tend to be more lenient towards those early societies than towards modern societies living in an urban environment. At the same time, there are examples of environmental activities in ancient times that resulted in long-lasting changes, the signs of which are observable even today. The cutting down of large areas of forests for building ships in ancient times might have contributed to the decrease of woodland coverage in the Balkan Peninsula, and in the territory of Greece. However, the drier 
summers and droughts in the Mediterranean might also have contributed to this largescale reduction of woodland areas (Karatzas, 2000).

Nevertheless, this latter fact has no relation to human activities. In Greece, owing to the low summer precipitation, the stunted plants and bushes that develop are suitable only for grazing of sheep and goats. By overgrazing the slopes of mountains, these animals increase soil erosion. The thin soil layer becomes loose and is transported from the slopes by winter runoff, creating barren limestone surfaces quite rapidly as a final and complete stage of erosion. There are several examples of deforestation in other regions as well. During the reign of King Solomon, cedar woodlands covered an area of $5000 \mathrm{~km}^{2}$. Cedar woodlands were first mentioned in the literature between $2500 \mathrm{BC}$ and $2300 \mathrm{BC}$. However, very few cedars are found there today. In the golden age of the Roman Empire the main road from Baghdad to Damascus was shadowed throughout by cedars. Today, the road between these cities is surrounded by desert (McNeill, 2001).

Several cultures emphasize that one should live in harmony with the environment. However, even in those societies, where this idea has been perpetually mentioned (e.g. in Asian societies), environmental ideas got frequently lost under the pressure of financial demands.

Air pollution problems of ancient times are mentioned even in the poems of classical poets. Horace ( 65 BC- 8 AD) wrote that Roman buildings turned more and more dark from smoke, and this phenomenon might have been observed in many other ancient cities. Seneca (4 BC to 65 AD), the teacher of Emperor Nero (37-68 AD), was in poor health all his life and his physician frequently advised him to leave Rome. In one of his letters to Lucilius in $61 \mathrm{AD}$ he mentions that he must escape from the gloomy smoke and kitchen odours of Rome in order to get better (Heidorn, 1978).

Sextus Julius Frontinus (30-100 AD), once governor of Britain, later oversaw water supply to imperial Rome (recorded his book De Aquaeductu Urbis Romae) and believed his actions also improved Rome's air. Civil claims over smoke pollution were brought before Roman courts almost 2000 years ago (Brimblecombe, 1987b). According to the Roman law, cheese-making premises should be established in such way so that their smoke would not to pollute other houses. Much similar material is available from the very important book Pan's Travail (Hughes, 1993) and in Brimblecombe (1987a).

The Roman Senate introduced a law about 2000 years ago, according to which: Aerem corrumpere non licet, namely 'Polluting air is not allowed'. The Institutes issued under the Roman emperor Justinian in 535 AD were used as a text in law schools. Under the section Law of Things, our right to the air is clear: 'By the law of nature these things are common to mankind - the air, running water, the sea, and consequently the shores of the sea.' (Lib. II, Tit. I : Et quidem naturali iure communia sunt omnium haec: aer et aqua profluens et mare et per hoc litora maris).

\section{Lead mining and exploitation}

In the ancient Mediterranean, mining and metallurgy played a primary role in the economy. According to Xenophon (434-359 BC) and Lucretius (98-55 BC), the smoke of lead mines in Attica was harmful to human health (Weeber, 1990).

Lead is extracted from its most important ore, galena. The lead content of galena is $86.6 \%$, but it also contains arsenic, tin, antimony and silver. The major part of silver production of the world comes from galena and not from silver ore, because mining and 
exploitation of galena is much more significant. For a long time after the introduction of silver coin as a currency (about $2700 \mathrm{BC}$ ), the primary aim of galena mining was to extract silver, and lead was considered to be only a by-product (Boutron, 1995).

The oldest lead object found by archaeologists is a string of beads worn in Anatolia some 8000 years ago. Its use as jewellery suggests that this was a time when lead was still new and rare (Eisinger, 1984). Lead mining started about $4000 \mathrm{BC}$, but significant exploitation began some 1000 years later, when a new smelting technology was introduced in order to extract lead (and silver) from sulfide ores of lead. The exploitation of lead ores and the use of lead became more and more important during the Copper, Bronze and Iron Ages (Nriagu, 1983a). This progress was promoted by the introduction of silver coins and the development of Greek civilization (during that time lead production was 300 times higher than that of silver). Lead production reached its maximum of 80000 tonnes a year in the golden age of the Roman Empire, which was about the same magnitude as that of the Industrial Revolution some 2000 years later (Hong et al., 1994). The most important lead mines were situated in the Iberian Peninsula, the Balkans, in the territory of ancient Greece, and in Asia Minor (Nriagu, 1983a). Lead production suddenly decreased after the fall of the Roman Empire, and reached its minimum at about $900 \mathrm{AD}$, with a mass of only some 1000 tonnes a year. Then production began to increase again, thanks to the new lead and silver mines opened in Central Europe after about 1000 AD.

\section{The uses of lead}

Lead mines during Roman times were a plentiful source of the metal, as Pliny describes lead being found 'in the surface stratum of the earth in such abundance that there is a law prohibiting the production of more than a certain amount' (Waldron, 1973). In Roman times lead was the most popular metal, and was widely used in everyday life. It has a number of useful properties that suit it to a relatively low level of technology. It melts at low temperatures, it is malleable and easy to work, it can be readily cast and joined, and it is resistant to corrosion. Thus it comes as no surprise that it found such widespread application in the ancient world (Waldron, 1985). Its compounds were used as face powders, lipstick or mask paint, as well as colouring agents in paints. Furthermore, lead was used for preserving foods; it was even portioned to wine in order to prevent its fermentation. Lead compounds were used as a birth control medicine (for exterminating sperms) and a kind of a spice, too. Cups, jugs, pots and frying pans were made of lead alloys. Coins were made of lead, as well as of alloys of lead and other metals such as copper, silver and gold. Since it resists corrosion and can be processed easily, lead was extensively used in shipbuilding and house building, and it was used for the construction of water pipes as well. During house building, hot lead was poured between limestone/marble blocks and in this way it served as a binder. In ancient Rome and in other cities of the Roman Empire, the construction of water pipes was the most important use for lead. Also, in Babylon a water pipe made of lead was used to water the hanging gardens built by king Nabu-kudurri-usur [Nabukodonosor, 605-562 BC]. Because of the above-mentioned facts lead is frequently referred to as a Roman metal (Eisinger, 1984; Markham, 1994). 


\section{Illnesses caused by lead}

Both metallic lead and its compounds are poisonous. Thanks to its slight volatility (lead vapour) and mouldering (lead powder) as well as the volatility and solubility of some of its compounds (e.g. lead tetraethyl and lead diacatate), it can easily get absorbed in the human body. Symptoms of lead poisoning are headache, nausea, diarrhoea, fainting and cramp.

The Romans knew that lead was a dangerous metal, because they noticed the symptoms suffered by people who worked in lead mines. Pliny wrote: 'red-lead is a deadly poison and should not be used medicinally' as well as warned that the 'exhalations from silver mines (i.e. galena mines) are dangerous to all animals' (Waldron, 1973). Furthermore, the geographer Strabo described (about 7 BC) the high chimneys required to disperse the air pollutants during silver production in Spain. However, because lead was used extensively in everyday life, the risks were deemed acceptable. Lead was believed to be less dangerous if it got into the body only in small doses. As carbon dioxide dissolved in water comes into contact with lead in water pipes, resulting in a possible enrichment of these dissolved lead compounds in the body, this process can easily lead to the so-called 'lead disease', a consequence of which might be paralysis. The presence of lead in food and drinking water might have led to infertility or stillbirth (Goldstein, 1988). Nevertheless, mineworkers suffered most from the harmful effects of lead, hence the Romans generally made slaves work in mines. In Greek and Roman times, according to estimations, several hundred thousand people (mainly slaves) died from acute lead poisoning during the mining and smelting processes (Nriagu, 1983a; 1983b; Hong et al, 1994).

The credit for the first direct clinical account of lead poisoning has in recent times been accorded to Hippocrates (Waldron, 1973).

The use of lead water systems represented a hazard to health but both the Romans and the Greeks exposed themselves to a far greater risk. They found that by coating their bronze or copper cooking pots with lead or lead alloys, not only was the leaching of copper from the pot prevented, thus avoiding spoiling the taste of the food but also these were a great value in preparing wine and grape syrup (sapa) which was used almost exclusively as a sweetening agent. Pliny also advocated this dangerous practice. He writes 'Preference should be given to lead vessels ... in boiling defrutum and sapa' (Waldron, 1973). One property of lead is to inhibit enzyme activity, hence sapa prevented fruit souring and fermenting and was used extensively as a preservative. In addition, sapa was found to improve the quality of a poor wine and to prolong the length of time for which any wine could be kept (Waldron, 1973). The adoption of lead as a sweetener for wine in medieval Europe caused widespread illness (Eisinger, 1991).

To some authors the extreme behaviour of Emperors Caligula (12-41 AD) and Nero might also be the consequences of lead poisoning (Goldstein, 1988). No aspect of the history of lead is likely to provoke as much interest and controversy as the prevalence of chronic lead disease (deriving from extensive lead mining and the wide usage of devices made of lead) in antiquity, and the suggestion that it played an important part in the decline of the Roman Empire (Nriagu, 1983a; 1983b; Hong et al., 1994). On the other hand, there are some reasons why this idea may be largely discredited: (a) the lead-related gluttony and other excesses of the Julio-Claudian and Flavian emperors are difficult to reconcile with the loss of appetite and constipation that are among the prominent symptoms of chronic plumbism; (b) the Empire attained its greatest wealth, power and 
extent under Trajan and other effective emperors, who also consumed food and drinks prepared in lead-made devices (Waldron, 1985); (c) most of the lead in the bones from citizens of Rome has come from post-mortem absorption. It is suggested that it was mainly gradual depopulation that contributed to the failure of the Western Empire, and lead-induced infecundity may have played only a small part in this (Eisinger, 1984). The rise of Christianity might have also been a major reason (Zeek, 1986). The decline of the Roman Empire is a phenomenon of great complexity and it is too simple to ascribe it to a single cause.

In the 20th century, lead compounds deriving from tetraethyl-lead, which have been used for many decades as anti-knock additives in fuel, have caused severe environmental pollution. Lead compounds, depositing from the atmosphere onto the agricultural plants, can get into the body either through the food chain or via inhalation. Petrol chemistry has only recently achieved the replacement of tetraethyl-lead by another compound, which proved to be relatively environmentally friendly from the aspect of lead poisoning (Boutron, 1995).

\section{Lead pollution of ancient tooth samples in the United Kingdom}

English researchers, co-fellows of the Natural Environment Research Council and the British Geological Survey, studied the concentrations of lead in tooth enamels from Romano-British and early medieval people from various sites in the United Kingdom. Then, they compared the lead concentrations present in these people both with those of their prehistoric forebears and with those of people living in the United Kingdom today. According to an extensive study on the tooth enamel lead concentration of adults living in the United Kingdom, carried out in the early 1980s, the concentrations of lead displayed spatial variations with an average of $3 \mathrm{ppm}$. More recent analyses of children's teeth found lead concentrations with averages around a few tenths of a part per million, suggesting, as indicated also by the atmospheric data, that modern lead exposure is decreasing. Neolithic people, living before the use of metals, had tooth enamel lead concentrations that averaged around $0.3 \mathrm{ppm}$.

While analysing tooth enamels of Roman, Anglo-Saxon and Viking people living in the United Kingdom, researchers found individuals with tooth lead concentrations greater than $10 \mathrm{ppm}$, and occasionally even higher values. Concentrations of this magnitude among modern people can be associated with occupational or acute exposure, and suggest that lead pollution was a significant problem for both Roman and the early medieval ancestors of British citizens.

The explanation may be the fact that England, Scotland, Wales and Ireland are all rich in natural lead deposits. Furthermore, each of these countries has abundant ores, which have been mined since antiquity. Probably, it was partly the richness of the country's lead ores, with their associated silver of course, that led to Rome's initial interest in the conquest of this most northerly reach of the Empire. It is also known that the RomanoBritish, Anglo-Saxon and Viking people inhabiting the area of the United Kingdom were exposed predominantly to lead from the ore sources, because of the characteristic isotopic composition of the lead remaining in their teeth.

On the other hand, high exposures were detected not only among the people actively involved in lead mining, smelting or metal working, but in the tooth enamels of children too. Thus a high lead concentration was considered to be an environmental rather than occupational problem. 


\section{Lead pollution on regional and hemispheric scales}

In 1957-58, as part of the International Geophysical Year, the first extensive research programmes were launched to analyse information stored in snow and ice layers of Greenland and the Antarctic that are many hundreds of thousands of years old. The aim of this research was to establish a possible hemispheric scale of air pollution for a time period spanning many thousand years. Later, these ice cores provided substantial information on the atmospheric effects of human activities (e.g. Boutron et al., 1991, 1993, 1994).

In Greenland, the deepest boring, of 9000 feet (2750 metres), corresponds to an interval of 7760 years, which is well before the time when silver was first smelted from galena. We can speak about the background levels of the atmospheric lead concentration up to this period (Boutron, 1995). The chemical analysis of this ice core indicated that the lead concentration in the atmosphere before the beginning of lead production, when atmospheric lead derived only from natural sources, was low. At this time, the enrichment factor of the atmospheric lead was near 1 (0.8), which indicated that this lead derived from soils and rocks. Around 3000 years ago, the lead concentration of the atmosphere practically corresponded to the levels measured at the beginning of lead production. This means that anthropogenic lead emission was still negligible up to this time, considering the amount of lead getting into the atmosphere naturally. The atmospheric concentration of lead started to increase in the 5th century, and during the Greek-Roman times (between $400 \mathrm{BC}$ and $300 \mathrm{AD}$ ) the enrichment factor of lead reaching the value of 4 and remaining at the same high level for seven centuries. Thus, a four times higher lead concentration was detected for this period in the snow and ice layers of Greenland compared with the earlier, natural values. This has been the earliest detected hemispheric scale air pollution, almost 2000 years before the industrial revolution and well before any other polluting effect (Hong et al., 1994).

In the golden age of the Roman Empire, about 2000 years before, 5\% of the total processed lead (80000 tonnes) got into the atmosphere, which might have resulted in an atmospheric emission peak of 4000 tonnes a year (Hong et al., 1994). Lead emission derived from metal processing caused important local and regional air pollution all over Europe, which has been detected, for example, in the lacustrine deposits of southern Sweden (Renberg et al., 1994). Furthermore, these emissions significantly polluted the troposphere over the Arctic (Hong et al., 1994).

Rosman et al. (1993) examined the possible sources of lead pollution in the ancient atmosphere. According to the analysis of lead isotope ratios in ice cores, the mines in the territory of Spain proved to be the main sources of atmospheric lead. These mines were supervised by the Carthaginians between 535 and 205 BC, and they were followed by the Romans till 410 AD. About $70 \%$ of lead in the ice layers of Greenland in the period between $150 \mathrm{BC}$ and $50 \mathrm{AD}$ comes from the mines of Rio Tinto, in the south-eastern part of Spain.

During the Greek-Roman age, an important part of the fourfold increase of lead concentration in the troposphere over Greenland came from lead/silver mining and processing. During the time of the Roman Empire, $40 \%$ of the lead production in the world came from Spain, Central Europe, Britain, Greece and Asia Minor (Nriagu, 1983a). Lead was smelted in open furnaces, for which the rate of emission was not checked. The 
escaping small aerosol particles could easily reach the Arctic region, via routes which have become known only recently (Hong et al., 1994).

After the fall of the Roman Empire, the atmospheric lead concentration suddenly dropped to the background level, which was characteristic 7760 years ago. In the Medieval and Renaissance Ages it began to increase again, and 471 years later it reached a concentration double that detected during the Roman Empire (Boutron, 1995). In the 17 th century scientists identified widely such as illnesses in mining areas that were thought to arise from dispersion of the toxic elements (Brimblecombe, 1987b). Afterwards, the increase was continuous following the industrial revolution. From the 1930s till about 1960, snow and ice samples in Greenland indicated a rapid increase. This can be traced back to the anti-knock additives in leaded fuels, which were used first in 1923 (Nriagu, 1990). On a global scale, two-thirds of the lead additives were used by the USA in the 1970 s, $70 \%$ of which got directly into the atmosphere via the exhaust gases of vehicles. Atmospheric lead concentrations measured in the 1960s were about 200 times higher than the natural values. This is one of the most serious ever recorded global-scale pollutions of the environment on Earth (Boutron, 1995). The sudden decrease, observed from 1970, can be traced back to an increasing use of unleaded fuels. Recently, all petrol sold in the USA, and a gradually increasing ratio sold in Europe, is unleaded (Nriagu, 1990). Recently, Eurasia has been responsible for $75 \%$ of the atmospheric lead concentration on the Earth (Rosman et al., 1993).

Lead pollution in the atmosphere has been detected over the Antarctic since the beginning of the 20th century. The use of leaded fuels and then their cutback can also be detected. Furthermore, it has been established that an important part of anthropogenic lead comes from South America (Boutron, 1995). At the same time, natural concentration changes of lead (and other heavy metals) were also considerable over the Antarctic during past ages. Low concentration values were detected in the Holocene period, and the lead concentration was two orders of magnitude higher than this during the last glacial maximum, about 20000 years ago (Boutron and Patterson, 1986).

\section{Copper mining and exploitation}

Originally (about 7000 years ago), copper was produced from native copper, and this was the main procedure for about 2000 years. The discovery and introduction of a new smelting technique of oxide and carbonate ores, as well as the appearance of tin-bronze, then brought the development of the real Bronze Age, when the production of copper increased continuously. In the period between $2000-700 \mathrm{BC}$, total production was about 500000 tonnes (Tylecote, 1976).

Copper production suddenly increased in the Roman times, when copper alloys were used more and more intensively and frequently, both for military and civil purposes (e.g. minting). The production reached its maximum 2000 years ago with a mass of about 15000 tonnes a year. In this period, the main copper mines were situated in the territory of Spain (half of the total production of the world derived from this country, from the regions of Huelva and Rio Tinto), in Cyprus and Central Europe (Hong et al., 1996a). The total production, in the period between $250 \mathrm{BC}$ and $350 \mathrm{AD}$, was about 5 million tonnes (Healy, 1988). 
Generally speaking, the peaks/decreases of the production of any metal correspond to the booms and busts of the country. This statement is valid for both the Roman Empire and China. A decrease of mining of all metal ores, including copper, started with the weakening of the Roman Empire. After the fall of the Empire, copper production decreased significantly in Europe. World production stagnated at about 2000 tonnes a year until the 8th century and then started to increase again. This increase, from the European side, was especially due to the opening of new mines in the 9th century in the territory of Germany, and in the 13th century in Sweden (the latter particularly in the region of Falun) (Pounds, 1990).

Outside the Roman Empire, important copper production occurred in Southwest Asia and in the Far East. When the Han dynasty (206 BC-220 AD) extended its influence over Southwest Asia, copper production in China was about 800 tonnes a year. In the medieval age, most of the world production came from China (during the rule of the northern Sung dynasty). In this period, the Chinese production reached its maximum of 13000 tonnes a year, and this resulted in the peak world production of 15000 tonnes a year in the $1080 \mathrm{~s}$. Most of the copper was used for minting (Archaometallurgy Group, Beijing University of Iron and Steel Technology, 1978). For some centuries after this period, production suddenly dropped (about 2000 tonnes a year in the 14th century), and then started to increase again from the industrial revolution until recently. (In comparison, the total copper production of the world was 10000 tonnes a year at the beginning of the industrial revolution.) In Japan, the extensive production of copper used in the manufacture of giant Buddhist statues gave rise to widespread environmental pollution from the 8th century (Satake, 2001).

\section{Copper pollution on regional and hemispheric scales}

Before the beginnings of anthropogenic use of copper, about 7000 years ago, the total atmospheric copper was derived solely from natural sources and the situation did not change until 2500 years ago. Since then, the atmospheric copper concentration has increased, which is a consequence of large-scale copper pollution in the northern hemisphere (Hong et al., 1996b).

Copper emissions from ancient times until recently have been the result of mining and metallurgical activities. Other anthropogenic activities (e.g. the production of iron and non-ferrous metals, wood burning) contribute to these emissions only to a small extent.

Emissions linked to these production processes, in connection with significant technological developments, have changed considerably during the past 7000 years. In ancient times, owing to the primitive smelting procedures, the emission factor was about $15 \%$. At the beginning, several steps in the processing of sulfide ores (roasting, smelting, oxidation and cleaning) were performed in open furnaces. Emission has been taken out of consideration until the industrial revolution. From this time onwards, more developed furnaces and improved metallurgical procedures started to spread. Since the middle of the 19th century, the processing procedure has been reduced to five steps. These technological developments have resulted in a significant decrease of the emission factor. In the 20th century, this factor came down to only $1 \%$ and later, with the introduction of further modifications, it became a mere 0.25\% (Hong et al., 1996a, 1996b). 
Since Roman times, the $\mathrm{Cu} / \mathrm{Al}$ ratio has increased in ice samples, which indicates considerable copper pollution in the troposphere over the Arctic in this period. This copper might have originated during the high-temperature section of the processing as small-sized aerosol particles, and got into the atmosphere. These aerosols can easily reach the Arctic region from the middle latitudes where they originated (in Roman times: mainly the Mediterranean Basin, especially Spain; in the medieval ages: China).

Changes of the $\mathrm{Cu} / \mathrm{Al}$ ratio in the ice samples seem to correspond to the estimated changes of anthropogenic copper emission. Data derived from the ice cores in Greenland indicate low values until 2500 years ago, medium values from the Roman times until the industrial revolution, and suddenly increasing values near the recent period. Data from the Roman times show high variability. This can probably be traced back to the fact that, in this period, the production of copper occurred in short bursts, depending on how many copper coins were needed (Hong et al., 1996b).

According to the ice samples in Greenland, comparing production data with emission factors, the atmospheric copper emission peaked twice in the period before the industrial revolution. The first peak occurred in the golden age of the Roman Empire about 2000 years ago, with a mass of some 2300 tonnes a year, when the use of metal coins spread in the Mediterranean region. The second peak appeared in the golden age of the northern Sung dynasty (960-1279 AD) in China, at about 1080 AD, with a mass of some 2100 tonnes a year, when the Chinese economy was extensively developing and copper production increased. Because the smelting technology was primitive at that time, about $15 \%$ of the smelted copper got into the atmosphere. Though the total copper emission of the Roman and Sung times was about a tenth of that in the 1990s, copper production did not reach even a hundredth of that in the recent period. Hemispheric copper pollution caused by copper emissions has a more than 2500 year old history, and copper emissions of the Roman and Sung times were higher than at any time until 1750 (Hong et al., 1996a).

\section{Environmental awareness in the ancient Israel}

The environment is a natural issue of concern for Judaism. Much of the discussion centres around the Biblical commandment of 'bal taschit'; i.e. not to destroy, without purpose, any object from which someone might derive pleasure. Trees, fields and rivers belonged to this circle. Jewish people knew that trees were very important and, for this reason, they prohibited the cutting down of trees around cities. Furthermore, trees were required to be watered and the environment to be cared for. Any form of luxury was prohibited, because luxury itself is a kind of waste. Beyond the prohibition of actual destruction, an entire series of laws deals with maintaining the general environmental quality of life. The Talmud requires:

- That one must not open a shop in a courtyard if the noise pollution of customers will disturb his neighbours' sleep;

- That one must put the pigeon cotes at least 50 cubits from the town walls, so that the poops would not damage the town's vegetable gardens; 
- That threshing floors must also be kept at this distance, to prevent the chaff from creating an air pollution problem for the city. So too carrion, graves and tanneries also have this same distance requirement because of the odours they produce.

The fifth book of Moses is the basis of Jewish ecology. It specified, among other things, that soldiers were prohibited to relieve themselves on the field of the camp. They should leave the camp, then dig a hole, and when they are finished, they should bury it. It was prohibited to build latrines near the houses because they were malodorous. Because smells dissipate in different ways in winter and in summer, sewage channels were prohibited to be open during the summer. If anybody suffered from the sewage of another person, he/she could claim compensation. Sewage was not allowed to be released near kitchen gardens, because it decreased the yields. All this was natural to the Jewish people, and they still believe that one should live the same way even recently, as it had been written in the Bible, the Torah and the Talmud.

The Biblical cities in Israel were surrounded by a migrash - an area of 1000 cubits left for public enjoyment in which nothing may intrude. For this reason trees must be kept 25 to 50 cubits (depending on the species of tree and the amount of shade each species provides) from the city wall. Furthermore, according to the rabbis, the migrash may not be turned into a field, as it destroys the beauty of the city. Interestingly, a field cannot be made into a migrash, as it will diminish the crops. In the Temple service, olive wood and wood from grapevines are prohibited for use on the altar. One opinion holds that the reason for this is concern for the settlement and cultivation of the land of Israel. The second opinion is much more specific. These types of wood burn with a great deal of smoke and air pollution is to be avoided.

Jerusalem, as the holiest of the cities, also had special environmental legislation designed to protect its unique environment for the enjoyment of its inhabitants and visitors. In that regard, all garbage was removed from the city, dunghills were prohibited from the city area and no kilns were allowed to operate within its border. In this way, vermin and smoke were kept out of the city and the quality of life was improved (Mészáros, 2001). Tanning factories should be settled at least 60 cubits from the city wall, because they were particularly smelly. They were prescribed to have been built to the eastern side of the city, because in Israel northerly and westerly winds were generally the most frequent, and in this way, the stench would not get back to the city. Mills were allowed to be built at least 50 cubits from the city wall, because when they were operating much dust got into the air, which was harmful to humans when inhaled. Furthermore, it was held that wheat powder was not only unhealthy, but harmful for the fields, too. So, mills should where possible be built far away from fields. On the other hand, one can read in the Talmud that smoke is not only bad and harmful, but destroys the Garden of Eden of God as well. Hence, the relationship between God and humans becomes worse and they draw away from each other. The Talmud also says that the soul of God lives in everything: in animals and plants and stones, etc. Therefore, He must not be offended, because if God had wanted a smoky world he would have created it. In the law-book of Tosefta it was written that it was prohibited to wash in drinking water. Each well should be covered by a roof so that snakes, insects and vicious souls could not to attack the water in it. Sewage holes were not allowed to be dug near the neighbour's well. The Jewish lawbooks dealt with noise pollution, too. Millstones caused a lot of noise and vibration during work. For this reason, mills were not allowed to be established near the city. The operation of a school (a big one was considered to have at least 50 students) depended on 
the inhabitants of the neighbouring houses, because children are noisy and this could disturb the inhabitants (Bal Tashchit, 5th Book of Moses).

This raises the question of why rabbis dealt so much with the environment in the past and why this environmental sensitivity was pushed into the background. The answer might be that Jewish people didn't have farms for a long time, and thus didn't feel themselves to be close to the nature. Therefore, they didn't appreciate the value of the field as much as their ancestors did. But now that they could go back to their real homes, they perhaps will listen to the sounds of nature and their environment more carefully. According to the proverb, 'The clean Jewish people take better care of their environment, than the dirty Romans' (Bal Tashchit, $5^{\text {th }}$ Book of Moses).

\section{Acknowledgement}

The authors thank Claude F. Boutron (Laboratoire de Glaciologie et Géophysique de l'Environment du Centre National de la Recherche Scientifique, Unité de Formation et de Recherche de Mécanique Université Joseph Fourier, Grenoble, France) for an exceptionally comprehensive contribution, Lajos Rácz (Department of History, Juhász Gyula Teachers' Training Faculty, University of Szeged; Hungary) for valuable help and advice, and Noa Feller, Ian Strachan and Keith Boucher for their useful hints on the topic.

\section{References}

Archaeometallurgy Group, Beijing University of Iron and Steel Technology (1978) A Brief History of Metallurgy in China, Science Press, Beijing.

Bal Tashchit, 5th Book of Moses.

Boutron, C.F. and Patterson, C.C. (1986) 'Lead concentration changes in Antarctic ice during the Wisconsin/Holocene transition', Nature, Vol. 323, pp. 222-225.

Boutron, C.F. (1995) 'Historical reconstruction of the Earth's past atmospheric environment from Greenland and Antarctic snow and ice cores', Environmental Review, Vol. 3, pp. 1-28.

Boutron, C.F., Görlach, U., Candelone, J.P., Bolshov, M.A. and Delmas, R.J. (1991) 'Decrease in anthropogenic lead, cadmium and zinc in Greenland snows since the late 1960s', Nature, Vol. 353 , pp. 153-156.

Boutron, C.F., Rudniev, S.N., Bolshov, M.A., Koloshnikov, V.G., Patterson, C.C. and Barkov, N.I. (1993) 'Changes in cadmium concentrations in Antarctic ice and snow during the past 155,000 years', Earth and Planetary Science Letters, Vol. 117, pp. 431-444.

Boutron, C.F., Candelone J.P. and Hong, S. (1994) 'Past and recent changes in the large scale tropospheric cycles of $\mathrm{Pb}$ and other heavy metals as documented in Antarctic and Greenland snow and ice: a review', Geochimica et Cosmochimica Acta, Vol. 58, pp. 3217-3225.

Brimblecombe, P. (1987a) The big smoke. A history of air pollution in London since medieval times, Methuen, London, New York, 184 p. ISBN 0416900801.

Brimblecombe, P. (1987b) 'The antiquity of smokeless zones', Atmospheric Environment, Vol. 21, No. 11, pp. 2485-2485.

Brimblecombe, P. (1995) 'History of air pollution', in Singh, H.B. (Editor) Composition, Chemistry and Climate of the Atmosphere, Van Nostrand Reinhold, pp. 1-18. New York

Brimblecombe, P. and Pfister, C. (1990) The silent countdown. Essays in European Environmental History, Springer-Verlag, Berlin, Heidelberg, New York, ISBN 3540517901. 
Chun, Y. (2000) 'The yellow-sand phenomenon recorded in the Chosunwangjosilok', Journal of the Meteorological Society of Korea, Vol. 36, pp. 285-292.

Driver, G.R. and Miles, J.C. (1952) The Babylonian Laws Legal Commentary, Clarendon Press.

Eisinger, J. (1984) 'Lead in history and history in lead', Nature, Vol. 307, No. 5951, pp. 573-573. (see also Nriagu, 1983a).

Eisinger, J. (1991) 'Early consumer protection legislation - a $17^{\text {th }} \mathrm{C}$ law prohibiting lead adulteration of wines', Interdisciplinary Science Reviews, Vol. 16, pp. 61-68.

Epstein, R. (1992) 'Pollution and the environment', Vajra Bodhi Sea: A Monthly Journal of Orthodox Buddhism, Pt. 1, v. 30, pp. 36, 12.

Goldstein, E. (Editor) (1988) Pollution, Social Issues Resources Series, Inc., Boca Raton FL, 182 p., ISBN 0897771060

Hartwell, R. (1967) 'A cycle of economic change in Imperial China: coal and iron in northeast China, 750-1350', Journal of the Economic and Social History of the Orient a Journal d'Histoire economique et sociale de l'Orient, Vol. 10, pp. 102-159.

Healy, J.F. (1988) Mining and Metallurgy in the Greek and Roman World, Thames and Hudson, London.

Heidorn, K.C. (1978) 'A chronology of important events in the history of air pollution meteorology to 1970', Bulletin of American Meteorological Society, Vol. 59, pp. 1589-1597.

Hong, S., Candelone, J.P., Patterson, C.C. and Boutron, C.F. (1994) 'Greenland ice evidence of hemispheric lead pollution two millennia ago by Greek and Roman civilizations', Science, Vol. 265, pp. 1841-1843.

Hong, S., Candelone, J.P., Soutif, M. and Boutron, C.F. (1996a) 'A reconstruction of changes in copper production and copper emissions to the atmosphere during the past 7000 years', The Science of the Total Environment, Vol. 188, pp. 183-193.

Hong, S., Candelone, J.P., Patterson, C.C. and Boutron, C.F. (1996b) 'History of ancient copper smelting pollution during Roman and medieval times recorded in Greenland ice', Science, Vol. 272, pp. 246-249.

Hughes, J.D. (1993) Pan's Travail, John Hopkins.

Karatzas, K. (2000) 'Preservation of environmental characteristics as witnessed in classic and modern literature: the case of Greece', The Science of the Total Environment, Vol. 257, pp. 213-218.

Karatzas, K. (2001) Some historical aspects of urban air quality management. The Third International Conference on Urban Air Quality and Fifth Saturn Workshop. Measurement, Modelling and Management, 19-23 March 2001, Loutraki, Greece, Institute of Physics, Extended Abstracts CD-ROM, Canopus Publishing Limited.

Makra, L. (2000) Wandering in China, Változó Világ 37, Press Publica Kiadó, Budapest, 128 p. ISSN 1219 5235; ISBN 9639001406 (in Hungarian)

Mamane, Y. (1987) 'Air-pollution control in Israel during the $1^{\text {st }}$ and $2^{\text {nd }}$ century', Atmospheric Environment, Vol. 21, No. 8, pp. 1861-1863.

Markham, A. (1994) A Brief History of Pollution, Earthscan, London.

McNeill, J.R. (2001) Something New Under the Sun. An environmental history of the twentiethcentury world, W.W. Norton \& Company - New York - London, ISBN 0393321835

Mészáros, E. (2001) A Short History of the Earth, Vince Publisher Ltd, Budapest, 168 p, ISBN 963 919288 0; ISSN 14176114 (in Hungarian)

Mészáros, E. (2002) 'The mankind and the environment before the industrial revolution', História, Vol. 5, No. 6, pp. 21-24. (in Hungarian)

Nriagu, J.O. (1983a) Lead and Lead Poisoning in Antiquity, Wiley, New York.

Nriagu, J.O. (1983b) 'Occupational exposure to lead in ancient times', Science of the Total Environment, Vol. 31, pp. 105-116. 
Nriagu, J.O. (1990) 'The rise and fall of leaded gasoline', Science of the Total Environment, Vol. 92, pp. $12-38$.

Pounds, N.J.G. (1990) A Historical Geography of Europe, Cambridge, London.

Renberg, I., Persson, M.W. and Emteryd, O. (1994) 'Pre-industrial atmospheric lead contamination detected in Swedish lake sediments', Nature, Vol. 368, pp. 323-326.

Rosman, K.J.R., Chisholm, W., Boutron, C.F., Candelone, J.P. and Görlach, U. (1993) 'Isotopic evidence for the sources of lead in Greenland snows since the late 1960s', Nature, Vol. 362, pp. 333-335.

Satake K.(2001) 'New eyes for looking back to the past and thinking of the future', Water Air and Soil Pollution, Vol. 130, Nos 1-4, pp. 31-42.

Schäfer, E.H. (1962) 'The conservation of nature under the Tang Dynasty', Journal of Economic and Social History of the Orient, Vol. 5, pp. 299-300.

Turco, R.P. (1997) Earth and Seige: From Air Pollution to Global Change, Oxford University Press, Oxford.

Tylecote, R.F. (1976) A History of Metallurgy, Mid-County, London.

Waldron, H.A. (1973) 'Lead poisoning in the ancient world', Medical History, Vol. 17, pp. 39199.

Waldron, H.A. (1985) 'Lead and lead poisoning in antiquity', Isis, Vol. 76, No. 281, pp. 118-120 (see also Nriagu, 1983a).

Weeber, K.W. (1990) Smog über Attika: Umveltverhalten im Altertum,. Artemis, Zürich

Zeek, W.C. (1986) 'Lead and lead poisoning in antiquity', Technology and Culture, Vol. 27, pp. 129-30 (see also Nriagu, 1983a). 